\title{
Virulence of Blumeria graminis f. sp. tritici Populations in Morocco
}

\author{
Yasmina Imani and Abdallah Ouassou, Department of Agronomy and Plant Breeding, Institut Agronomique et \\ Vétérinaire Hassan II, BP 6201, Rabat-Instituts, Rabat, Morocco; and Carl A. Griffey, Department of Crop and \\ Soil Environmental Sciences, Virginia Polytechnic Institute and State University, Blacksburg 24061-0404
}

\begin{abstract}
Imani, Y., Ouassou, A., and Griffey, C. A. 2002. Virulence of Blumeria graminis f. sp. tritici populations in Morocco. Plant Dis. 86:383-388.

The incidence and severity of powdery mildew, caused by Blumeria graminis f. sp. tritici, have increased in Morocco during the past decade as a result of the introduction and intensive production of a few semidwarf cultivars of bread wheat (Triticum aestivum) and durum wheat (Triticum turgidum) that are genetically uniform, and the increased utilization of nitrogen fertilizers and irrigation. The virulence of the pathogen population has not been characterized in Morocco, and little is known about the spectra and distribution of virulence in B. graminis populations. Such knowledge will facilitate the identification and utilization of effective resistance genes in cultivar development and deployment. Isolates of B. graminis collected in 1999 and 2000 from three Moroccan wheat production areas were analyzed for virulence using a host differential series comprised of 13 known genes conferring resistance to powdery mildew. Segments of primary leaves from 12-day-old seedlings of the wheat differentials were inoculated with isolates of $B$. graminis derived from a single pustule. Powdery mildew reactions were assessed on a 0 to 9 scale 12 days after inoculation. Virulence frequencies, complexity, and racial composition of the pathogen population were determined. Data were analyzed for associations among pairs and triplets of virulence genes and for distribution of virulence genes among pathotypes. High frequencies of virulence to genes $P m 1, P m 3 \mathrm{c}, P m 3 \mathrm{f}, P m 4 \mathrm{a}, p m 5$, and $P m 7$ were found over both years and across all three regions. Frequencies of virulence for $P m 17$ and $P m 2$ were intermediate, while virulence frequencies for Pm $3 \mathrm{a}, P m 3 \mathrm{~b}, P m 3 \mathrm{~d}$, and $P m 4 \mathrm{~b}$ were low. Virulence to $P m 8$ increased to high levels, while virulence to $P m 4$ a decreased across the area surveyed from 1999 to 2000 . The random distribution of virulence genes among pathotypes indicates that sexual reproduction contributes to the variability of the pathogen. The Moroccan population of Blumeria graminis f. sp. tritici is composed of complex and highly variable pathotypes ( $87 \%$ of the isolates had five or more virulence genes), and strategies for deployment of resistance genes should take into account this complexity.
\end{abstract}

Additional keywords: Erysiphe graminis f. sp. tritici, gene associations, gene-for-gene hypothesis, race specific resistance

Powdery mildew, caused by Blumeria graminis (DC.) E.O. Speer f. sp. tritici Ém. Marchal (syn. Erysiphe graminis f. sp. tritici), is one of the most important foliar diseases of wheat (Triticum aestivum L.) in regions with a cool or maritime climate. This disease has become more significant in semiarid regions as a result of changes in irrigation, increased use of nitrogen fertilizer, and widespread use of a few semidwarf cultivars that are genetically uniform (18). In a survey of wheat diseases in Morocco, Ramdani and Ibriz (14) reported that from 1997 to 1999 incidence and severity of wheat powdery mildew increased from 31 to $50 \%$.

Use of resistant cultivars provides the most economical and environmentally safe

Corresponding author: Yasmina Imani

E-mail: y.imani@iav.ac.ma

Accepted for publication 8 August 2001.

Publication no. D-2002-0212-02R

(C) 2002 The American Phytopathological Society tion and independence of virulence genes in the pathogen population. Hence, the objective of this study was to determine and characterize the virulence spectra of $B$. graminis f. sp. tritici populations in Morocco using isolates collected in three regions of the country over 2 years.

\section{MATERIALS AND METHODS}

Collection of isolates. Isolates of the wheat powdery mildew pathogen, $B$. graminis f. sp. tritici, were obtained from infected leaves collected in commercial fields in Morocco during 1999 and 2000. The surveyed region covered three agroecological areas (Fig. 1). Area 1 is the Atlantic coastal plain where the climate is mild and bread (Triticum aestivum L.) and durum (Triticum turgidum L.) wheat are grown. In this area, the wheat crop is grown with or without irrigation under marginal production conditions. Area 2 is the Gharb, a partially irrigated coastal plain north of Rabat where some fields are irrigated and durum wheat production predominates. Area 3 is the Sais, a nonirrigated fertile lowland at the base of the northern part of the Middle Atlas Mountains where both durum and bread wheat are cultivated. The same roads were taken on each annual field survey, and stops were made every 10 to $15 \mathrm{~km}$. Surveys were conducted during late March and April, and the wheat host plants were between anthesis and milk growth stages at the time of collection. A 5-cm-long section of diseased leaf was collected at each site, placed in a petri dish filled with benzimidazole agar $(0.5 \%$ agar amended with 50 $\mathrm{mg}$ of benzimidazole per liter), and taken to the laboratory in a cooler. A total of 24 samples in 1999 and 30 samples in 2000 were collected over the three regions.

Single-colony isolation and maintenance of isolates. In the laboratory, petri dishes containing the infected leaf segments were placed in a growth chamber at 17 to $18^{\circ} \mathrm{C}$ for $48 \mathrm{~h}$ with $12 \mathrm{~h}$ of illumination $\left(75 \mu \mathrm{E} \cdot \mathrm{m}^{-2} \cdot \mathrm{s}^{-1}\right)$ provided by fluorescent lights to promote sporulation. A single-colony isolate of the pathogen was obtained from each sample. $B$. graminis f. sp. tritici conidia were transferred from a single isolated pustule to fresh detached leaves of the susceptible cultivar Fartas using a paint brush. These petri dish cultures were incubated under the same conditions as described above and were transferred to new wheat leaves every 12 to 14 days. Single-colony isolates, derived after 
three to four cycles of single pustule transfers to establish pure cultures, were used in subsequent tests to characterize virulence of the pathogen populations.

Virulence analysis. Virulence of each single-pustule isolate was assessed on a host differential set using 3-cm-long segments cut from the middle part of the primary leaf of 12-day-old seedlings laid on benzimidazole agar $(0.5 \%$ agar, $50 \mathrm{mg}$ of benzimidazole per liter). The host differential set (Table 1) was comprised of wheat genotypes provided by S. Leath, USDAARS, Raleigh, NC; J. Clarkson, NIAB, Cambridge, U.K.; and G. Doussinault, INRA, Rennes, France. This set included seven of the cultivar Chancellor (abbreviated as $\mathrm{Cc}$ ) near-isogenic lines for powdery mildew resistance developed by Briggle (2). Chancellor was used as the susceptible control in all experiments, and Fartas, a fully susceptible local cultivar, was used for the maintenance and multiplication of inoculum. All wheat lines were grown in $10 \times 10 \mathrm{~cm}$ plastic pots filled with a mixture of one-third peat and two-thirds sand. Seedlings were grown in a growth chamber at $20^{\circ} \mathrm{C}$ with $12 \mathrm{~h}$ illumination $\left(75 \mu \mathrm{E} \cdot \mathrm{m}^{-}\right.$ ${ }^{2} \cdot \mathrm{s}^{-1}$ ) in wooden cages covered with a plastic film to prevent any contamination.

The methods of inoculation, conditions of incubation, and disease assessment were performed according to Niewoehner and Leath (13). For each single-pustule isolate screened in this study, three leaf segments of each wheat genotype were assessed and three independent tests were performed. Primary leaf segments from 12-day-old seedlings were placed on benzimidazole agar in petri dishes. The leaf segments were inoculated in a miniature settling tower comprised of a 0.75 -liter cup with a $1.5-\mathrm{cm}$ opening at the top for insertion of the infected leaf segment used to aerially distribute spores to the petri plate below.
After inoculation, petri dishes were placed in a growth chamber at 17 to $18^{\circ} \mathrm{C}$ with 12 $\mathrm{h}$ of light $\left(75 \mu \mathrm{E} \cdot \mathrm{m}^{-2} \cdot \mathrm{s}^{-1}\right)$ per day. The leaf segments were rated 12 days after inoculation using the modified scale of Leath and Heun (11) where: $0=$ immune, no visible signs or symptoms; 1 = highly resistant, small flecks only; 2 = resistant, chlorotic flecks evident; 3 = resistant, large flecks with chlorosis and necrosis; 4 = intermediate, mycelium and conidia barely detectable; $5=$ moderately susceptible, small to moderate-sized pustules and conidia present, $6=$ moderately susceptible, predominance of moderate-sized pustules and conidia present; 7 = susceptible, at least $50 \%$ of the leaf segment covered with large pustules and conidia; $8=$ susceptible, 75 to $80 \%$ of the leaf segment covered with large pustules and conidia; $9=$ susceptible, $100 \%$ of the leaf segment covered with large pustules and conidia.

Data analyses. Virulence genes present in the Moroccan population of B. graminis f. sp. tritici were determined based on the reaction of host differential lines to the different isolates according to the gene-forgene hypothesis (7). Susceptibility of a differential line carrying a known resistance gene to a specific isolate indicated the presence of the corresponding virulence gene in that isolate. For each virulence gene and each year, virulence frequencies were determined based on the proportion of isolates inducing an intermediate to susceptible reaction (infection types 4 to 9) as described by Niewoehner and Leath (13).

Virulence genes were categorized into three classes based on observed frequencies. The first class contains genes observed at nil or low frequencies $(\leq 10 \%)$. The second class contains genes observed at intermediate frequencies $(>10$ and $\leq 40 \%$ ), and the third class includes genes



Fig. 1. Agroecological areas of cereal production in Morocco showing the origin of the Blumeria graminis f. sp. tritici isolates collected in 1999 and 2000. Area $1=$ Atlantic Coast, $2=$ Gharb, $3=$ Sais. observed at high frequencies $(>40 \%)$. For each year, pathotypes were defined on the basis of the virulence-avirulence formula, and isolates having the same formula were grouped together in order to determine the racial composition of the pathogen population. The distribution of the number of virulence genes per isolate was analyzed for each year by comparing the observed distribution to the Poisson distribution using a $\chi^{2}$ test. The theoretical values were calculated using the recurrence formula relative to Poisson law (4). A $\chi^{2}$ statistical test was used to compare the observed and expected values of pairs and triplets of virulence genes based on independent assortment. The data for 1999 and 2000 were combined, and only the combinations with expected values higher than five were analyzed on the basis of conditions established for chi-square tests (4). All pairs and triplets of genes were analyzed for the 13 resistance loci listed in Table 1.

\section{RESULTS}

Incidence and frequency of virulence genes. A total of 54 isolates of B. graminis f. sp. tritici that were collected from three distinct regions in Morocco were characterized for virulence on the 13 host differentials in 1999 and 2000. Over the three regions, virulence was identified for all resistance genes in 2000 and for 12 of the 13 resistance genes in 1999 (Table 2). Virulence of the isolates for genes $P m 1$, $P m 3 \mathrm{c}, P m 3 \mathrm{f}, p m 5$, and $P m 7$ occurred at high frequencies over the 2 years and across the three regions, while isolates with virulence for genes $P m 3 \mathrm{a}, P m 3 \mathrm{~b}$, and $P m 4 b$ occurred at the low frequencies. Virulence was not identified for gene Pm3a in 1999 at any location. While the frequency of isolates with virulence for $P m 3 d$ was moderately high in the Gharb region,

Table 1. Cereal investigation (CI) or plant introduction (PI) numbers and listing of resistance genes in the near-isogenic lines and cultivars of wheat used to characterize virulence of Blumeria graminis f. sp. tritici isolates from three Moroccan wheat production areas

\begin{tabular}{lll}
\hline Host differential & $\begin{array}{l}\text { Accession } \\
\text { number }\end{array}$ & $\begin{array}{c}\text { Resistance } \\
\text { gene }\end{array}$ \\
\hline Axminster / 8*Cc & CI 14114 & $P m 1$ \\
Ulka / 8* Cc & CI 14118 & Pm2 \\
Asosan / 8* Cc & CI 14120 & $P m 3 \mathrm{a}$ \\
Chull / 8* Cc & CI 14121 & Pm3b \\
Sonora / 8* Cc & CI 14122 & Pm3c \\
Rolle & None & Pm3d \\
MichiganAmber / & CI 14033 & $P m 3 \mathrm{f}$ \\
$8^{*}$ Cc & & \\
Khapli / 8* Cc & CI 14123 & $P m 4 \mathrm{a}$ \\
Renan & None & $P m 4 \mathrm{~b}$ \\
Hope / 8* Cc & CI 14125 & $p m 5$ \\
Transec & CI 14189 & $P m 7$ \\
Kavkaz & PI 361879 & $P m 8$ \\
Amigo & CI 17609 & $P m 17$ \\
Chancellor & CI 12333 & $\ldots{ }^{z}$ \\
\hline
\end{tabular}

${ }^{\mathrm{y}} \mathrm{Cc}=$ Chancellor.

${ }^{\mathrm{z}}$ No known genes for powdery mildew resistance. 
virulence for this gene was not identified in the Atlantic Coast or Sais populations in either year.

Isolates collected from the Atlantic coast region in 1999 cumulatively possessed virulence for 11 of the 13 resistance genes evaluated, while virulence for 9 resistance genes was identified in 2000. Across years, virulence was identified for all resistance genes tested except for Pm3a and Pm3d. Frequency of isolates with virulence for genes Pm2 and Pm4b was 8\% in 1999 but was not detected in 2000. All isolates collected from this region in 1999 had virulence for gene Pm4a, while only 50\% of the isolates collected in 2000 had virulence for this gene. The frequency of isolates possessing virulence for genes $P m 3 \mathrm{~b}, P m 8$, and Pm17 increased from 1999 to 2000 , and all isolates collected in 2000 had virulence for $P m 8$.

A significant increase in the total number of virulence genes was observed in the pathogen population of Gharb from 1999 to 2000. Isolates collected in 2000 had virulence for all 13 resistance genes tested, while in 1999 virulence for genes Pm3a, $P m 3 b, P m 4$ b, and $P m 8$ was not identified. Frequency of isolates with virulence for genes Pm3d, Pm4a, and Pm17 declined from 1999 to 2000, while the frequency of isolates having virulence for gene $P m 3 \mathrm{~b}$ increased.

In the Sais region, virulence for genes $P m 3$ a, Pm3b, Pm3d, and $P m 4$ b was not detected in 1999, while in 2000 virulence for all resistance genes except $P m 3 \mathrm{~d}$ was identified. Frequency of isolates with virulence for gene $P m 17$ declined from 1999 to 2000, and virulence for gene Pm2 increased slightly, while virulence for gene Pm8 nearly tripled.

Over the three locations, the most consistent and notable changes observed from 1999 to 2000 in the pathogen population was a dramatic increase in the frequency of isolates having virulence to gene $\operatorname{Pm} 8$ and a decline in the frequency of isolates possessing virulence for gene $P m 4 a$. In the Gharb region, virulence for gene $P m 8$ was not identified in 1999 but occurred at $45 \%$ in 2000. In the Atlantic coast region, virulence for Pm8 more than doubled to $100 \%$ in 2000. In the Sais region, virulence frequency for $P m 8$ was $25 \%$ in 1999 , but nearly tripled to $70 \%$ in 2000 . Frequency of isolates with virulence for gene Pm4a declined by $50 \%$ or more in the Atlantic coast and Gharb regions and declined by $20 \%$ in the Sais region.

Characterization of pathotypes. For each year, isolates of $B$. graminis f. sp. tritici were classified on the basis of their virulence-avirulence formulae (Tables 3 and 4). In 1999, 16 different pathotypes were identified among 24 isolates collected from the Atlantic coast, Gharb, and Sais regions (Table 3). Only two of the 16 pathotypes were isolated from more than one region. Fifty percent of the pathotypes
Table 2. Virulence frequencies of Blumeria graminis f. sp. tritici isolates collected in 1999 and 2000 from three Moroccan wheat production areas

\begin{tabular}{|c|c|c|c|c|c|c|}
\hline \multirow{3}{*}{$\begin{array}{l}\text { Resistance } \\
\text { gene }\end{array}$} & \multicolumn{6}{|c|}{ Virulence frequency $(\%)$} \\
\hline & \multicolumn{2}{|c|}{ Atlantic coast ${ }^{x}$} & \multicolumn{2}{|c|}{ Gharby $^{y}$} & \multicolumn{2}{|c|}{ Sais $^{z}$} \\
\hline & 1999 & 2000 & 1999 & 2000 & 1999 & 2000 \\
\hline$P m 1$ & 92 & 100 & 100 & 100 & 100 & 100 \\
\hline$P m 2$ & 8 & 0 & 25 & 45 & 25 & 30 \\
\hline$P m 3 a$ & 0 & 0 & 0 & 18 & 0 & 10 \\
\hline$P m 3 b$ & 8 & 25 & 0 & 27 & 0 & 20 \\
\hline$P m 3 \mathrm{c}$ & 58 & 75 & 75 & 72 & 75 & 80 \\
\hline$P m 3 d$ & 0 & 0 & 50 & 27 & 0 & 0 \\
\hline$P m 3 f$ & 83 & 87 & 100 & 100 & 87 & 100 \\
\hline$P m 4 a$ & 100 & 50 & 100 & 45 & 100 & 80 \\
\hline$P m 4 \mathrm{~b}$ & 8 & 0 & 0 & 27 & 0 & 20 \\
\hline$p m 5$ & 75 & 87 & 100 & 100 & 75 & 100 \\
\hline$P m 7$ & 100 & 100 & 100 & 100 & 100 & 100 \\
\hline Pm8 & 42 & 100 & 0 & 45 & 25 & 70 \\
\hline Pm 17 & 17 & 25 & 50 & 27 & 50 & 30 \\
\hline
\end{tabular}

${ }^{x}$ Coastal plain south of Rabat with mild climate and where bread and durum wheat are grown under marginal production conditions.

y Partially irrigated coastal plain north of Rabat where durum wheat production predominates.

${ }^{\mathrm{z}}$ Nonirrigated fertile lowland at the base of the northern part of the Middle Atlas Mountains.

Table 3. Origin and frequency of pathotypes of Blumeria graminis f. sp. tritici collected in 1999

\begin{tabular}{|c|c|c|c|}
\hline Virulence/avirulence & $\operatorname{Region}(\mathbf{s})$ & $\begin{array}{l}\text { Virulence } \\
\text { genes (\#) }\end{array}$ & $\begin{array}{c}\text { Frequency } \\
(\%)\end{array}$ \\
\hline $4 \mathrm{a}, 5,7 / 1,2,3 \mathrm{a}, 3 \mathrm{~b}, 3 \mathrm{c}, 3 \mathrm{~d}, 3 \mathrm{f}, 4 \mathrm{~b}, 8,17$ & Atlantic Coast & 3 & 4.16 \\
\hline $1,4 \mathrm{a}, 5,7 / 2,3 \mathrm{a}, 3 \mathrm{~b}, 3 \mathrm{c}, 3 \mathrm{~d}, 3 \mathrm{f}, 4 \mathrm{~b}, 8,17$ & Saïs & 4 & 4.16 \\
\hline $1,3 \mathrm{f}, 4 \mathrm{a}, 7 / 2,3 \mathrm{a}, 3 \mathrm{~b}, 3 \mathrm{c}, 3 \mathrm{~d}, 4 \mathrm{~b}, 5,8,17$ & Atlantic Coast & 4 & 8.3 \\
\hline $1,3 \mathrm{f}, 4 \mathrm{a}, 5,7 / 2,3 \mathrm{a}, 3 \mathrm{~b}, 3 \mathrm{c}, 3 \mathrm{~d}, 4 \mathrm{~b}, 8,17$ & Atlantic Coast & 5 & 4.16 \\
\hline $1,3 \mathrm{f}, 4 \mathrm{a}, 7,17 / 2,3 \mathrm{a}, 3 \mathrm{~b}, 3 \mathrm{c}, 3 \mathrm{~d}, 4 \mathrm{~b}, 5,8$ & Saïs & 5 & 4.16 \\
\hline $1,3 \mathrm{f}, 4 \mathrm{a}, 5,7,17 / 2,3 \mathrm{a}, 3 \mathrm{~b}, 3 \mathrm{c}, 3 \mathrm{~d}, 4 \mathrm{~b}, 8$ & Gharb & 6 & 4.16 \\
\hline $1,3 \mathrm{c}, 3 \mathrm{f}, 4 \mathrm{a}, 5,7 / 2,3 \mathrm{a}, 3 \mathrm{~b}, 3 \mathrm{~d}, 4 \mathrm{~b}, 8,17$ & Atlantic Coast, Saïs & 6 & 16.6 \\
\hline $1,3 \mathrm{c}, 3 \mathrm{f}, 4 \mathrm{a}, 7,17 / 2,3 \mathrm{a}, 3 \mathrm{~b}, 3 \mathrm{~d}, 4 \mathrm{~b}, 5,8$ & Atlantic Coast, Saïs & 6 & 8.3 \\
\hline $1,3 \mathrm{~b}, 4 \mathrm{a}, 5,7,8,17 / 2,3 \mathrm{a}, 3 \mathrm{c}, 3 \mathrm{~d}, 3 \mathrm{f}, 4 \mathrm{~b}$ & Gharb & 7 & 4.16 \\
\hline $1,3 \mathrm{c}, 3 \mathrm{f}, 4 \mathrm{a}, 5,7,17 / 2,3 \mathrm{a}, 3 \mathrm{~b}, 3 \mathrm{~d}, 4 \mathrm{~b}, 8$ & Gharb & 7 & 4.16 \\
\hline $1,3 \mathrm{c}, 3 \mathrm{f}, 4 \mathrm{a}, 5,7,8 / 2,3 \mathrm{a}, 3 \mathrm{~b}, 3 \mathrm{~d}, 4 \mathrm{~b}, 17$ & Saïs & 7 & 4.16 \\
\hline $1,3 \mathrm{c}, 3 \mathrm{~d}, 3 \mathrm{f}, 4 \mathrm{a}, 5,7 / 2,3 \mathrm{a}, 3 \mathrm{~b}, 4 \mathrm{~b}, 8,17$ & Gharb & 7 & 8.3 \\
\hline $1,3 \mathrm{c}, 3 \mathrm{f}, 4 \mathrm{a}, 4 \mathrm{~b}, 5,7,8 / 2,3 \mathrm{a}, 3 \mathrm{~b}, 3 \mathrm{~d}, 17$ & Atlantic Coast & 8 & 8.3 \\
\hline $1,2,3 \mathrm{c}, 3 \mathrm{f}, 4 \mathrm{a}, 5,7,8 / 3 \mathrm{a}, 3 \mathrm{~b}, 3 \mathrm{~d}, 4 \mathrm{~b}, 17$ & Atlantic Coast & 8 & 4.16 \\
\hline $1,2,3 \mathrm{c}, 3 \mathrm{f}, 4 \mathrm{a}, 5,7,17 / 3 \mathrm{a}, 3 \mathrm{~b}, 3 \mathrm{~d}, 4 \mathrm{~b}, 8$ & Saïs & 8 & 8.3 \\
\hline $1,2,3 \mathrm{c}, 3 \mathrm{f}, 4 \mathrm{a}, 5,7,8,17 / 3 \mathrm{a}, 3 \mathrm{~b}, 3 \mathrm{~d}, 4 \mathrm{~b}$ & Gharb & 9 & 4.16 \\
\hline
\end{tabular}

Table 4. Origin and frequency of pathotypes of Blumeria graminis f. sp. tritici collected in 2000

\begin{tabular}{|c|c|c|c|}
\hline Virulence/avirulence & $\operatorname{Region}(\mathbf{s})$ & $\begin{array}{l}\text { Virulence } \\
\text { genes (\#) }\end{array}$ & $\begin{array}{c}\text { Frequency } \\
(\%)\end{array}$ \\
\hline $1,3 \mathrm{c}, 7,8 / 2,3 \mathrm{a}, 3 \mathrm{~b}, 3 \mathrm{~d}, 3 \mathrm{f}, 4 \mathrm{a}, 4 \mathrm{~b}, 5,17$ & Atlantic Coast & 4 & 3.33 \\
\hline $1,3 \mathrm{f}, 5,7 / 2,3 \mathrm{a}, 3 \mathrm{~b}, 3 \mathrm{c}, 3 \mathrm{~d}, 4 \mathrm{a}, 4 \mathrm{~b}, 8,17$ & Gharb & 4 & 6.66 \\
\hline $1,2,3 \mathrm{c}, 3 \mathrm{f}, 7 / 3 \mathrm{a}, 3 \mathrm{~b}, 3 \mathrm{~d}, 4 \mathrm{a}, 4 \mathrm{~b}, 5,8,17$ & Saïs & 5 & 3.33 \\
\hline $1,3 \mathrm{f}, 4 \mathrm{~b}, 5,7 / 2,3 \mathrm{a}, 3 \mathrm{~b}, 3 \mathrm{c}, 3 \mathrm{~d}, 4 \mathrm{a}, 8,17$ & Saïs & 5 & 3.33 \\
\hline $1,3 f, 5,7,8 / 2,3 a, 3 b, 3 c, 3 d, 4 a, 4 b, 17$ & Atlantic Coast & 5 & 3.33 \\
\hline $1,2,3 \mathrm{c}, 3 \mathrm{f}, 5,7 / 3 \mathrm{a}, 3 \mathrm{~b}, 3 \mathrm{~d}, 4 \mathrm{a}, 4 \mathrm{~b}, 8,17$ & Gharb & 6 & 6.66 \\
\hline $1,3 \mathrm{~b}, 3 \mathrm{f}, 5,7,8 / 2,3 \mathrm{a}, 3 \mathrm{c}, 3 \mathrm{~d}, 4 \mathrm{a}, 4 \mathrm{~b}, 17$ & Atlantic Coast & 6 & 3.33 \\
\hline $1,3 \mathrm{c}, 3 \mathrm{f}, 5,7,8 / 2,3 \mathrm{a}, 3 \mathrm{~b}, 3 \mathrm{~d}, 4 \mathrm{a}, 4 \mathrm{~b}, 17$ & Atlantic Coast & 6 & 3.33 \\
\hline $1,3 \mathrm{f}, 4 \mathrm{a}, 5,7,8 / 2,3 \mathrm{a}, 3 \mathrm{~b}, 3 \mathrm{c}, 3 \mathrm{~d}, 4 \mathrm{~b}, 17$ & Gharb & 6 & 3.33 \\
\hline $1,2,3 \mathrm{c}, 3 \mathrm{f}, 5,7,8 / 3 \mathrm{a}, 3 \mathrm{~b}, 3 \mathrm{~d}, 4 \mathrm{a}, 4 \mathrm{~b}, 17$ & Saïs & 7 & 3.33 \\
\hline $1,2,3 \mathrm{c}, 3 \mathrm{f}, 4 \mathrm{a}, 5,7 / 3 \mathrm{a}, 3 \mathrm{~b}, 3 \mathrm{~d}, 4 \mathrm{~b}, 8,17$ & Gharb & 7 & 3.33 \\
\hline $1,3 \mathrm{a}, 3 \mathrm{c}, 3 \mathrm{f}, 5,7,8 / 2,3 \mathrm{~b}, 3 \mathrm{~d}, 4 \mathrm{a}, 4 \mathrm{~b}, 17$ & Saïs & 7 & 3.33 \\
\hline $1,3 \mathrm{~b}, 3 \mathrm{f}, 4 \mathrm{a}, 5,7,17 / 2,3 \mathrm{a}, 3 \mathrm{c}, 3 \mathrm{~d}, 4 \mathrm{~b}, 8$ & Saïs & 7 & 3.33 \\
\hline $1,3 \mathrm{c}, 3 \mathrm{f}, 4 \mathrm{a}, 5,7,8 / 2,3 \mathrm{a}, 3 \mathrm{~b}, 3 \mathrm{~d}, 4 \mathrm{~b}, 17$ & Atlantic Coast, Saïs & 7 & 13.3 \\
\hline $1,3 \mathrm{~b}, 3 \mathrm{c}, 3 \mathrm{f}, 4 \mathrm{a}, 5,7,8 / 2,3 \mathrm{a}, 3 \mathrm{~d}, 4 \mathrm{~b}, 17$ & Atlantic Coast & 8 & 3.33 \\
\hline $1,3 \mathrm{c}, 3 \mathrm{f}, 4 \mathrm{a}, 5,7,8,17 / 2,3 \mathrm{a}, 3 \mathrm{~b}, 3 \mathrm{~d}, 4 \mathrm{~b}$ & Atlantic Coast, Saïs & 8 & 9.99 \\
\hline $1,3 \mathrm{a}, 3 \mathrm{c}, 3 \mathrm{~d}, 3 \mathrm{f}, 4 \mathrm{a}, 5,7,8 / 2,3 \mathrm{~b}, 4 \mathrm{~b}, 17$ & Gharb & 9 & 3.33 \\
\hline $1,3 \mathrm{~b}, 3 \mathrm{c}, 3 \mathrm{~d}, 3 \mathrm{f}, 4 \mathrm{a}, 5,7,8 / 2,3 \mathrm{~b}, 4 \mathrm{~b}, 17$ & Gharb & 9 & 3.33 \\
\hline $1,3 \mathrm{~b}, 3 \mathrm{c}, 3 \mathrm{f}, 4 \mathrm{a}, 5,7,8,17 / 2,3 \mathrm{a}, 3 \mathrm{~d}, 4 \mathrm{~b}$ & Gharb & 9 & 3.33 \\
\hline $1,2,3 \mathrm{a}, 3 \mathrm{~b}, 3 \mathrm{c}, 3 \mathrm{f}, 4 \mathrm{a}, 5,7,17 / 3 \mathrm{~d}, 4 \mathrm{~b}, 8$ & Saïs & 10 & 3.33 \\
\hline $1,2,3 b, 3 c, 3 f, 4 a, 4 b, 5,7,8 / 3 a, 3 d, 17$ & Saïs & 10 & 3.33 \\
\hline $1,2,3 \mathrm{a}, 3 \mathrm{~b}, 3 \mathrm{c}, 3 \mathrm{f}, 4 \mathrm{~b}, 5,7,8,17 / 3 \mathrm{~d}, 4 \mathrm{a}$ & Gharb & 11 & 3.33 \\
\hline $1,2,3 \mathrm{~b}, 3 \mathrm{c}, 3 \mathrm{~d}, 3 \mathrm{f}, 4 \mathrm{a}, 4 \mathrm{~b}, 5,7,17 / 3 \mathrm{a}, 8$ & Gharb & 11 & 3.33 \\
\hline
\end{tabular}


had virulence for the combination of genes $P m 1, P m 3 \mathrm{c}, P m 3 \mathrm{f}, P m 4 \mathrm{a}, p m 5$, and $P m 7$. The 16 pathotypes possessed 3 to 9 virulence genes corresponding to the 13 resistance genes tested. The most abundant pathotype $(16.6 \%)$ possessed at least 6 virulence genes, and the mean number of virulence genes per isolate was 6.3. In 2000, 30 isolates were characterized, and 23 pathotypes possessing 4 to 11 virulence genes were identified. Twenty-one of the 23 pathotypes were derived from collections made in a single region, while two pathotypes were isolated from collections made in both the Atlantic coast and Sais regions. Sixty-five percent of the pathotypes possessed virulence for the combination of genes $P m 1, P m 3 \mathrm{c}, P m 3 \mathrm{f}, P m 4 \mathrm{a}$, $p m 5$, and $P m 7$. The most abundant pathotype $(13.3 \%)$ possessed at least 7 virulence genes, and the mean number of virulence genes per isolate was 6.8. All pathotypes identified in 1999 were different from those characterized in 2000 , but many pathotypes differed by only a single virulence gene, most often a loss of virulence for $P m 4 \mathrm{a}$ and/or the addition of virulence for $P m 8$.

The frequency of virulence genes per isolate was determined for each year on the basis of reaction to 13 differential lines tested. In 1999, more than $65 \%$ of the pathotypes possessed 6 to 8 virulence genes, while only one pathotype $(4.16 \%)$ possessed more than 8 virulence genes. In 2000 , more than $20 \%$ of the pathotypes possessed 9 to 11 virulence genes. Results of a chi-square test indicated that the differences between observed $\left(X_{\mathrm{obs}}{ }^{2}=12.32\right.$ for 1999 and 15.38 for 2000) and theoretical expected values $\left(X_{\exp }{ }^{2}=15.50\right.$ for 1999 and 18.30 for 2000) were not significant at the 0.05 level (Fig. 2). Over the 2 years, frequency distribution of the number of virulence genes among isolates conformed to a Poisson distribution, which indicates that the genes are randomly distributed among the isolates.

Association of virulence genes among pathotypes. The frequencies of 76 associations of gene pairs and 274 associations of gene triplets were analyzed over the com-

\section{A}

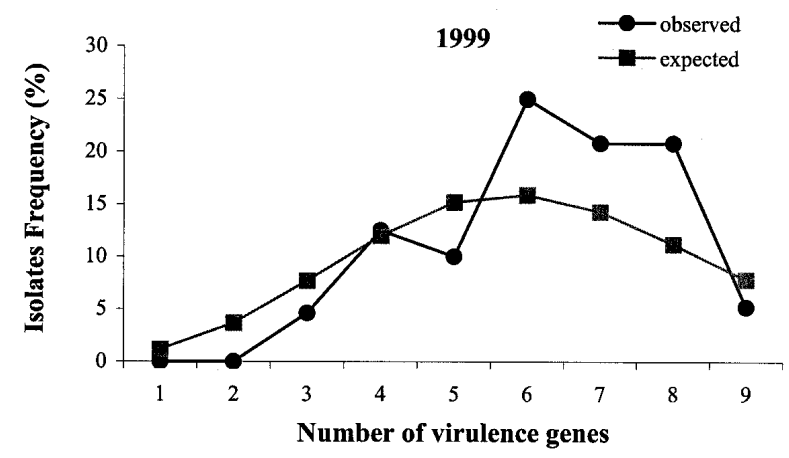

B

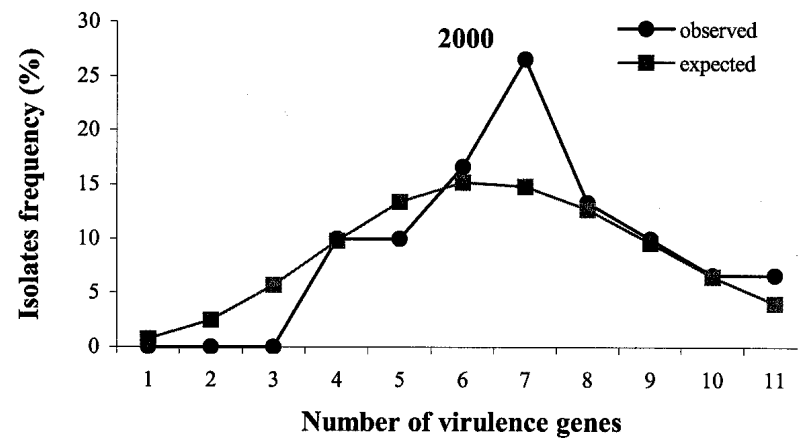

Fig. 2. Observed and expected distributions of the frequency of the number of virulence genes in isolates of Blumeria graminis f. sp. tritici collected in 1999 A, and 2000 B, in three Moroccan areas. Differences between observed $\left(X_{\mathrm{obs}}{ }^{2}=12.32\right.$ for 1999 and 15.38 for 2000) and expected $\left(X_{\exp }{ }^{2}=\right.$ 15.50 for 1999 and 18.30 for 2000 ) values were not significant at the 0.05 level.

bined data for both years of the study (Table 5). Among the 76 pairs of genes, 14 had a frequency significantly different than the product of the frequency of individual genes, which indicates that these pairs of virulence genes occurred together in the pathogen population to a greater or lesser extent than expected with normal recombination. For the other 62 pairs, the observed frequencies did not differ from the expected values, as expected with independent gene assortment. Among the 14 pairs, the $P m 1-P m 3 \mathrm{~b}$ and $P m 2-P m 8$ pairs of genes had frequencies lower than the expected values, and thus, were negatively associated. Among the 274 triplets of genes analyzed, 28 showed a frequency significantly different from the product of the frequency of individual genes. Among these, the Pm1-Pm3b-Pm3f and Pm1$P m 3 \mathrm{~b}-P m 8$ triplets of genes had frequencies lower than the expected values, and thus, were negatively associated.

\section{DISCUSSION}

Isolates of B. graminis f. sp. tritici characterized in this study were collected from commercial bread and durum wheat cultivars in three different regions of Morocco. For each virulence gene and for each year, virulence frequencies were based on the proportion of isolates inducing intermediate to susceptible reaction types (infection types 4 to 9 ). The classification of intermediate reaction types as virulent or avirulent has been addressed differently by researchers. Niewoehner and Leath (13) classified intermediate types as virulent, whereas Wolfe and Limpert (17) and $\mathrm{Na}$ muco et al. (12) classified intermediate types as avirulent. In the current study, tests for virulence of the isolates on wheat differential lines were based on infection types ranging from 0 to 9 . In most cases, infection types were either resistant ( 0 to 3 ) or susceptible ( 7 to 9 ) reactions.

Virulence was identified for all of the 13 resistance genes evaluated in the present study. Virulence for genes $P m 1, P m 3 \mathrm{c}$, $P m 3$ f, $p m 5$, and $P m 7$ occurred at frequencies of 58 to $100 \%$ over years and regions. In 1999, all pathotypes possessed virulence for gene $P m 4 \mathrm{a}$; however, virulence for this gene declined by 20 to $50 \%$ in 2000 . Overall, virulence for genes Pm3a, Pm3b, $P m 3 \mathrm{~d}$, and $P m 4 \mathrm{~b}$ occurred at the lowest frequencies. A significant increase in the frequency of pathotypes with virulence for gene $P m 8$ was observed in 2000 compared with 1999, while the frequency of pathotypes having virulence for Pm17 declined in two of the three regions.

Virulence spectrum of the $B$. graminis $\mathrm{f}$. sp. tritici population in Morocco can be compared with those of populations previously characterized in Europe $(3,5,6)$ and the United States (13). Virulence frequencies for Pm1 were low in the United States but high across the European continent. Felsenstein et al. (6) observed a north- 
south gradient for $P m 1$ virulence in Europe, with the highest frequencies occurring in southern France (78.5\%), northern Spain (90.25\%), and northern Italy $(79.8 \%)$. A high frequency of virulence for Pm 1 was also found in Morocco. High levels of virulence to $P m 2$ have been found across Europe and in the eastern United States $(3,13)$, while virulence frequencies remained intermediate in Morocco. Low virulence frequencies for $P m 3 \mathrm{a}$ and $P m 3 \mathrm{~b}$ have been found in western Europe and in Morocco, while high frequencies of virulence for $P m 3$ a have been reported in the United States, where this gene has been extensively deployed. High frequencies of virulence for genes $P m 3 \mathrm{c}, P m 3 \mathrm{f}$, and $P m 4 \mathrm{a}$ have been found across Europe, in North America, and in Morocco. Race-specific resistance based on commonly deployed genes such as $P m 1, P m 2, P m 3 c, P m 4$ a, $p m 5$, and $P m 8$ is no longer effective due to high frequencies of corresponding virulence genes, but some resistance genes such as Pm3a,Pm3b,Pm3d,Pm4b, and $P m 17$ remain effective in some regions of the world.

The differences among virulence frequencies observed in this study can be explained by changes in selection pressure favoring certain genes. Virulence frequencies are highly influenced by the resistance genes carried by cultivars grown in a particular area $(6,13)$. Since virulence frequencies were high for $P m 1, P m 3 \mathrm{c}, P m 3 \mathrm{f}$, $P m 4$ a, $p m 5$, and $P m 7$, these genes may be most prevalent in currently grown cultivars. On the other hand, genes with low virulence frequencies such as $P m 3 \mathrm{a}, P m 3 \mathrm{~b}$, $P m 3$ d, and $P m 4$ b may be rare or absent among Moroccan cultivars. Unfortunately, knowledge of deployed resistance genes in Moroccan commercial cultivars is limited, and these hypotheses cannot be confirmed at this time. Genetic analyses of resistance to powdery mildew of several common wheat cultivars and landraces from Mediterranean countries indicated that $p m 5$ was the most widely distributed resistance gene in this region. The occurrence of genes $P m 1, p m 5$, and combinations of $P m 1$ and pm5 with an unknown gene designated as " $u$ " have been identified in accessions from Morocco (18). Such data help to explain the occurrence of high levels of virulence observed for $P m 1$ and $p m 5$ in the present study.

Virulence for $P m 7$ is found in many countries, even where cultivars possessing this gene are not grown commercially (16). In the eastern part of the United States, virulence for $P m 7$ occurs at a high frequency, even though this gene has not been deployed in this country. There may be a selective advantage, or at least no disadvantage, to the fungus in carrying virulence to this particular gene (13), which may also be the case in Morocco. In the current study, a significant increase in the frequency of virulence for $P m 8$ was observed from 1999 to 2000. While this gene may be present in newer semidwarf cultivars that are being grown commercially, increased virulence may not be solely due to changes in cultivars grown. Isolates with virulence corresponding to $P m 8$ could possess a certain advantage, such as superior fitness, that may have contributed to this increase in frequency.

The ratio of number of identified pathotypes to the total number of isolates evaluated (0.68 for 1999 and 0.77 for 2000) indicates that the $B$. graminis f. sp. tritici population of Morocco lacks a predominant pathotype and is highly variable genetically. All pathotypes identified in 1999 were different from those characterized in 2000 . In 1999, isolates possessing 3 to 9 virulence genes were identified, and the most prevalent pathotypes (frequency of 25\%) had six virulence genes. In 2000, pathotypes possessing 4 to 11 virulence genes were identified, and the most prevalent pathotypes (frequency of 27\%) had 7 virulence genes. Considering that virulence was found for the 13 resistance genes tested in this study and pathotypes possessing combined virulence to as many as 11 of these genes were identified, it is unlikely that combinations of these race-specific genes will provide long-term durable resistance.

Presence and distribution of virulence genes among isolates conformed to a Poisson distribution indicating that virulence factors are randomly distributed among the different pathotypes during meiosis and sexual reproduction. In barley (Hordeum vulgare $\mathrm{L}$.), the winter and spring farming cycles provide a continuous bridge of hosts plants for asexual reproduction of mildew during the year. In many regions of northwestern Europe, barley mildew (Blumeria graminis DC. ex Mérat f. sp. hordei Em. Marchal) does not rely entirely on oversummering by means of cleistothecia (5). For wheat mildew, the bridge is not continuous. After harvest, host plants are not available for several weeks or months. Moreover, periods of plant growth more frequently occur during warm and dry weather conditions, which are unfavorable for continued formation of conidiospores. Wheat mildew may have to rely more heavily on formation of cleistothecia for its survival (5). In semiarid areas, such as Morocco, where the dry season is very long, cleistothecia represent the only means of survival of $B$. graminis f. sp. tritici. The high degree of variability of the pathogen population and lack of a predominant pathotype provide evidence that sexual reproduction and genetic recombination play an essential role in the life cycle of the pathogen. As mentioned above, complex pathotypes are predominant, and strategies for deployment of resistance genes should take into account this complexity. Control of powdery mildew via pyramiding resistance genes would likely not be effective in the long term. Presence of pathotypes carrying up to 11 virulence genes in the pathogen population

Table 5. Pairs and triplets of virulence genes of Blumeria graminis f. sp. tritici observed in isolates collected in 1999 and 2000

\begin{tabular}{|c|c|c|c|}
\hline Pairs of genes & Chi-square statistics ${ }^{y}$ & Triplets of genes & Chi-square statistics \\
\hline$P m 1-P m 3 b$ & 9.09 & $P m 1-P m 2-P m 3 \mathrm{f}$ & 34.03 \\
\hline$P m 1-P m 3 \mathrm{f}$ & 23.45 & $P m 1-P m 3 \mathrm{a}-P m 3 \mathrm{f}$ & 25.98 \\
\hline$P m 1-P m 4 \mathrm{~b}$ & 14.70 & $P m 1-P m 3 b-P m 3 \mathrm{f}$ & 29.97 \\
\hline$P m 1-P m 4 a$ & 13.82 & $P m 1-P m 3 b-P m 8$ & 18.75 \\
\hline$P m 2-P m 3 \mathrm{c}$ & 13.46 & $P m 1-P m 3 \mathrm{c}-P m 3 \mathrm{f}$ & 82.78 \\
\hline Pm2-Pm8 & 21.76 & $P m 1-P m 3 \mathrm{c}-P m 4 \mathrm{~b}$ & 53.29 \\
\hline Pm3b-Pm8 & 9.71 & $P m 1-P m 3 \mathrm{c}-P m 8$ & 19.15 \\
\hline$P m 3 \mathrm{c}-P m 3 \mathrm{f}$ & 9.20 & $\begin{array}{l}P m 1-P m 3 \mathrm{c}-P m 17 \\
P m 1-P m 4 \mathrm{a}-P m 17\end{array}$ & $\begin{array}{l}21.33 \\
14.39\end{array}$ \\
\hline$P m 3 c-P m 8$ & 9.50 & $P m 2-P m 3 c-P m 4 a$ & 14.83 \\
\hline$P m 3 \mathrm{~d}-P m 17$ & 26.47 & $P m 2-P m 3 c-P m 8$ & 19.91 \\
\hline$P m 3 \mathrm{f}-P m 4 \mathrm{~b}$ & 76.03 & $P m 3$ a- $P m 3 c-P m 8$ & 14.57 \\
\hline$P m 3 \mathrm{f}-P m 17$ & 27.29 & $P m 3 \mathrm{~b}-P m 3 \mathrm{c}-P m 4 \mathrm{~b}$ & 18.05 \\
\hline pm5-Pm8 & 14.09 & $P m 3 \mathrm{~b}-P m 3 \mathrm{c}-P m 8$ & 20.32 \\
\hline \multirow[t]{14}{*}{ Pm7-Pm17 } & 29.15 & $P m 3 b-P m 3 c-P m 17$ & 17.54 \\
\hline & & $P m 3 b-p m 5-P m 8$ & 17.98 \\
\hline & & Pm3b-Pm8-Pm 17 & 16.51 \\
\hline & & $P m 3 \mathrm{c}-P m 3 \mathrm{~d}-P m 8$ & 14.92 \\
\hline & & $P m 3 \mathrm{c}-P m 3 \mathrm{f}-P m 4 \mathrm{a}$ & 16.48 \\
\hline & & $P m 3 c-p m 5-P m 8$ & 17.9 \\
\hline & & $P m 3 \mathrm{c}-P m 3 \mathrm{f}-p m 5$ & 19.68 \\
\hline & & $P m 3 \mathrm{c}-P m 3 \mathrm{f}-P m 8$ & 17.52 \\
\hline & & $P m 3 \mathrm{c}-P m 4 \mathrm{~b}-P m 8$ & 2055 \\
\hline & & $P m 3 \mathrm{f}-p m 5-P m 8$ & 15.39 \\
\hline & & $P m 4 \mathrm{a}-P m 7-P m 8$ & 14.76 \\
\hline & & $P m 4 a-P m 7-P m 17$ & 25.56 \\
\hline & & $P m 4 b-P m 7-P m 8$ & 52.06 \\
\hline & & $p m 5-P m 8-P m 7$ & 22.79 \\
\hline
\end{tabular}

\footnotetext{
y Significant at the 0.05 level at $X^{2}>7.81$.
}

${ }^{\mathrm{z}}$ Significant at the 0.05 level at $X^{2}>14.1$. 
could induce rapid breakdown of resistance in cultivars carrying one or many resistance genes. The use of multiline cultivars offers the opportunity to replace any component of the mixture that becomes susceptible by a new resistant one. Efficiency of multiline cultivars has been confirmed for the control of genetically variable pathogens such as rusts and mildews (17). Race nonspecific resistance to powdery mildew has been identified and shown to be durable $(8,9)$. This type of resistance, known as slow mildewing or adult plant resistance, offers an alternative to the ephemeral hypersensitive major gene resistance.

Previous studies have reported associations between virulence factors in relationship to their occurrence, segregation, and maintenance in pathogen populations $(12,13,15)$. Significant positive associations between pairs or triplets of virulence genes may indicate selection pressure in favor of pathotypes carrying these combinations of virulence genes. The most frequent pairs and triplets of genes significantly associated in this study were between Pm1 and Pm3f (90\%); Pm1 and $P m 4 \mathrm{a}$ (72\%); pm3c and Pm3f (67\%); Pm1, $P m 3 \mathrm{c}$, and Pm3f (67.3\%); pm3c, Pm3f, and $p m 5$ (63\%); and Pm3c, Pm3f, and Pm4a (52\%). The association of virulence genes $P m 3 \mathrm{c}$ and $P m 3 \mathrm{f}$ was previously reported $(5,13,15)$. Royer et al. (15) reported an association between genes $P m 2$ and $p m 5$, and between $P m 3 \mathrm{c}$ and $P m 4 \mathrm{a}$, but these associations were not observed in the current study. Resistance genes $P m 7$ and $P m 17$ were derived from wheat-rye translocations and are associated with chromosomes 4A/2R and $1 \mathrm{AL} / 1 \mathrm{RS}$, respectively $(1,10)$. Niewoehner and Leath (13) reported an association between genes $P m 8$ and $P m 17$, both originating from rye, and suggested that the association of these two genes may be due to their common origin.
The current study is the first to provide a survey of B. graminis f. sp. tritici in Morocco. More information regarding resistant genes deployed in the host population is needed in order to fully explain the frequency of virulence genes and anticipate shifts in virulence. Additional studies including other regions and a larger sample of isolates have been planned to further analyze the diversity in Moroccan populations of B. graminis f. sp. tritici.

\section{AKNOWLEDGMENTS}

We thank B. Ezzahiri for critically reviewing the manuscript, S. Leath, J. Clarkson, and G. Doussinault for providing the differential lines, and M. Rached for technical assistance in conducting these studies.

\section{LITERATURE CITED}

1. Bennett, F. G. A. 1984. Resistance to powdery mildew in wheat: A review of its use in agriculture and breeding programs. Plant Pathol. 33:279-300.

2. Briggle, L. W. 1969. Near-isogenic lines of wheat with genes for resistance to Erysiphe graminis f. sp. tritici. Crop Sci. 6:461-465.

3. Clarkson, J. D. S., and Slater, S. E. 1999. Mildew of Wheat. Pages 22-28 in: UK Cereal pathogen virulence survey, 1999 Annual Report. United Kingdom Cereal Pathogen Virulence Survey Committee, Cambridge, England.

4. Dagnélie, P. 1984. Théories et Méthodes Statistiques, 2nd ed. Presses Agronomiques de Gembloux, Gembloux, Belgique.

5. Felsenstein, F. G. 1996. Effects of sexual reproduction on population dynamics of wheat and barley powdery mildew in Europe. Pages 91-96 in: Integrated control of cereal mildews and rusts: Towards coordination of research across Europe. Official Publications of the European Communities, Luxembourg.

6. Felsenstein, F. G., Limpert, E., and Fishbeck, G. 1991. Wheat mildew populations in the FRG and neighbouring regions-some aspects of their changes. Pages 1-7 in: Integrated Control of Cereal Mildews: Virulence Patterns and Their Changes. J. H. Jorgensen, ed. Risoe National Laboratory, Roskilde, Denmark.

7. Flor, H. H. 1956. Host-parasite interaction in flax rust: Its genetics and other implications Phytopathology 46:680-685.

8. Griffey, C. A., Das, M. K., and Stromberg, E L. 1993. Effectiveness of adult-plant resistance in reducing grain yield loss to powdery mildew in winter wheat. Plant Dis. 77:618622.

9. Gustafson, G. D., and Shaner, G. 1982. Influence of plant age on the expression of slowmildewing resistance in wheat. Phytopathology 72:746-749.

10. Heun, M., Friebe, B., and Bushuk, W. 1990. Chromosomal location of the powdery mildew resistance gene of Amigo wheat. Phytopathology 80:1129-1133.

11. Leath, S., and Heun, M. 1990. Identification of powdery mildew resistance genes in cultivars of soft red winter wheat. Plant Dis.74:747-752.

12. Namuco, L. O., Coffman, W. R., Bergstrom, G. C., and Sorrells, M. E. 1987. Virulence spectrum of the Erysiphe graminis f. sp. tritici population in New York. Plant Dis. 71:539541.

13. Niewoehner, A. S., and Leath, S. 1998. Virulence of Blumeria graminis f. sp. tritici on winter wheat in the eastern United States. Plant Dis. 82:64-68.

14. Ramdani, A., and Ibriz, H. 1999. Survey of wheat diseases in Morocco during three consecutive seasons 1997, 98 \& 99. Pages 25-31 in: Symposium regional sur les maladies des céreales et des légumineuses alimentaires. 1012 November 1999. Nabeul, Tunisie.

15. Royer, M. H., Nelson, R. R., and MacKenzie, D. R. 1984. An evaluation of the independence of certain virulence genes of $E$. graminis f. sp. tritici. Phytopathology 74:1007-1010.

16. Szunics, L., and Szunics, Lu. 1999. Wheat powdery mildew resistance genes and their application in practice. Acta Agron. Hung. 47(1):69-89.

17. Wolfe, M. S., and Limpert, E. 1986. Integrated control of cereal mildews: Monitoring the pathogen. Martinus Nijhoff Publishers, Dordrecht, Netherlands.

18. Zeller, F. J., Huang, X., Paderina, E. V., Collaku, A., Kowalczyk, K., Aslam, M., Peusha, H., and Hsam, S. L. K. 1998. Identification of powdery mildew resistance genes in common wheat (Triticum aestivum). XII. Cultivars and land races grown in Mediterranean countries. Plant Genet. Res. Newsl. 116:5-8. 